\title{
HUMANISTIC PUBLIC SERVICE EDUCATION IN GOVERNMENT GAMPING SUB-DISTRICT YOGYAKARTA
}

\author{
Halim Purnomo ${ }^{1}$, Moh. Toriqul Chaer ${ }^{2}$, Firman Mansir ${ }^{3}$ \\ ${ }^{1}$ Islamic Communication and Broadcasting Department, Universitas Muhammadiyah \\ Yogyakarta, Indonesia \\ ${ }^{2}$ Islamic Religious Education Department, STAI Masjid Syuhada Yogyakarta, Indonesia \\ ${ }^{3}$ Islamic Religious Education Department, Universitas Muhammadiyah Yogyakarta, Indonesia \\ Email: halimpurnomo@umy.ac.id ${ }^{1}$, toriqul210874@gmail.com², firmanmansir@umy.ac.id ${ }^{3}$
}

\begin{tabular}{l|l|l} 
Received: April 2021 & Accepted: July 2021 & Published: August 2021
\end{tabular}

\begin{abstract}
:
This article aims to explain how public services using a humanistic approach are organized by public service institutions to realize good governance. The public service agency under study is the District Government of Gamping Yogyakarta. The humanistic approach in providing public services in this study is understood as an approach that prioritizes humanist/humanitarian values. This study uses a qualitative approach to obtain complete information about public services carried out by public service actors in Gamping District, Yogyakarta, explored through observation, documentation, and in-depth interviews. The method used is the descriptive method, which describes several studies, public service policies from various works of literature. The results show that character education and the implementation of humanism values for service providers (government/political elites, bureaucratic apparatus) are critical and must be of higher quality and provide optimal satisfaction for the public service process service recipients.
\end{abstract}

Keywords: Education, Public Services, Humanists

\begin{abstract}
Abstrak:
Artikel ini bertujuan untuk menjelaskan bagaimana pelayanan publik dengan menggunakan pendekatan humanistik yang diselenggarakan oleh lembaga pelayanan publik guna mewujudkan good governance. Badan pelayanan publik yang diteliti adalah Pemerintah Kecamatan Gamping Yogyakarta. Pendekatan humanistik dalam penyelenggaraan pelayanan publik dalam penelitian ini dipahami sebagai suatu pendekatan yang digunakan dalam pelayanan publik dengan mengedepankan nilainilai humanis/kemanusiaan. Penelitian ini menggunakan pendekatan kualitatif, yaitu berusaha untuk memperoleh informasi selengkap mungkin tentang pelayanan publik yang dilakukan oleh para pelaku pelayanan publik di Kecamatan Gamping Yogyakarta, yang digali melalui observasi, dokumentasi, dan wawancara mendalam. Metode yang digunakan adalah metode deskriptif, yang menggambarkan beberapa penelitian, kebijakan layanan publik dari berbagai literatur. Hasil penelitian menunjukkan bahwa pendidikan karakter dan pemelakan nilai-nilai humanisme kepada penyedia jasa (pemerintah/elite politik, aparatur birokrasi) sangat penting dan harus dilakukan agar proses pelayanan publik dapat lebih berkualitas dan memberikan kepuasan optimal bagi penerima pelayanan.
\end{abstract}

Kata Kunci: Pendidikan, Pelayanan Publik, Humanis 


\section{INTRODUCTION}

Education is the most crucial step where humans have received education from their parents, siblings, and others from birth. So that those who did not know at first became aware of those who did not understand to understand and so on, especially humanism and religious education (Sari, 2013). as we get older, our knowledge will also increase. Humans cannot live alone. Surely they need other people to live in society between each other, living together must complement each other, please help, and understand each other. In whatever religious rules it adheres to and the nation's ideology, it is ordered to live to uphold the values of religious humanism, humanizing humans and obeying their Lord. Among them is the Almighty God and humanity that is just and harmonious, and many more are regulated in the Human Rights law and religious law (Asiah, 2017; Colbran, 2010).

Humans, aside from being individual individuals as well as social beings, indeed cannot live alone. A social being, in essence, can not live alone without any help from others or the community. The gathering of individuals with other individuals, individuals with groups, and groups with other groups will give birth to social institutions that require social norms as a foothold to actualize their behavior to be judged good and bad broadly as a religion that has universal teaching.

The rules in social life are written and unwritten, which have become part of the prevailing habits to become separate rules. What is referred to as custom is part of the unwritten rule. At the same time, written directions are often referred to as administrative rules, with their bureaucratic nature (Egan, 2016). Written rules generally are formed by a bureaucracy made by who issued them (institutions, associations, or even the government), so the process must be established by each institution that makes the rules. If so, then what needs to be paid attention to is how should those who make regulations and those who are regulated be able to understand their tasks and functions well, that smooth reciprocal communication can be realized so that public order can be realized in the administration of the government as well as possible. About government bureaucracy, for example, it is discovered that the government is essentially a public servant (by the public who needs it). For public services to be more functional, the bureaucracy needs to be neutral so that services provided through organizations or institutions supervised by the government can run optimally (Frederickson \& Hart, 1985; Yusriadi, 2018).

The policies and administration of the state relating to the implementation of approaches have been determined through political channels. Public service activities carried out by central government agencies, in the regions and the environment of state-owned or regional business entities in goods or services both in the context of efforts to meet the needs of the community or in the form of spending various policies as a follow-up effort to carry out public service activities.

Public service is a benchmark of the government's performance-the better the public service, the better the government's performance in the community's eyes. The public can assess the government's performance directly 
through public services performed (Kurniawan, 2016). In this research, the focus is on innovation in carrying out public services. The better the invention provided in running public services, the better the people's perception of public services.

A similar sentiment was also conveyed Rezha et al., (2013); the research results showed that service quality positively influences community satisfaction. This research explained that the joy of the people who received its service could be affected by several sub-variables: physical evidence, reliability, responsiveness, assurance, and empathy. Of course, in addition to understanding innovation in conducting services, it is necessary to improve the quality of public services.

Through humanism, education, of course, is an integrated form of effort to humanize human beings to shape character and realize the potentials that each human has to make it more human. On the other hand, support from a conducive environment is needed to learn the humanization process (Muali, 2017). Because, although humans tend to do good and love holiness, without the support of the environment, the potential will turn into negative potential. Therefore, to create a human education that provides maximum results, one must balance the two things: internal and external.

In addition, one approach to facilitating professional bureaucratic services is to use a humane approach, or what is referred to in this paper as a humanist paradigm. The humanist paradigm can be given the meaning that treating others must pay attention to the human side of that person, group, or society. This means that if individuals or groups become part of the public administration (public), providing services must also pay attention to the humanist side of the community it serves.

One approach or paradigm to facilitate professional bureaucratic services is to use a humane approach, referred to in this article as the humanist paradigm. The humanist paradigm can mean that a person treating others must pay attention to the human side of people, groups, or society. This means that if individuals or groups become part of the state administration (public), then in providing services, they must also pay attention to the human side of the community they serve. At least if the humanist concept in the bureaucracy carries out well, it will emerge as part of an ideal modern administration. This ideal type of current administration is identified with the following characteristics; 1) bureaucratic activities are carried out regularly with clear boundaries of authority; 2) there is a hierarchy of authority; 3 ) there are rules and regulations. There is a clear statement of employee behavior, authority, and responsibilities; and 4) employees are recruited based on a merit system, not on kinship ties (Prasodjo, 2016).

In carrying out public services, there must be such a thing as role models. The presence of this role model can have a good impact on others in conducting public services. Of course, the highest leadership in the agency must play the role model in carrying out optimal public services. Through this role model, it is hoped that other public servants can follow what has been done before. This is like Bandura's Social Learning theory which states that a person's behavior can 
change by observing the behavior of others around him (Nabavi \& Razieh, 2012; Lattimore et al., 2010), whereas Hutagalung (2015) suggest that someone can change their behavior after the person sees the behavior of others. Of course, this can not run without the support of superiors. The role of leaders is vital to be used as role models and so that behavior can be emulated well by subordinates (Selinger, 2019).

\section{RESEARCH METHODS}

Efforts to collect data in the field in this study specifically focused on ethnographer working models. The research site is public service education in the government Gamping sub-district, Yogyakarta. This study's data explain the implementation of humanist public service education. The method used is a descriptive method, which describes several studies, public service policies from various literature. The literature review results show that character education and the inculcation of human values to service providers (government/ political elites, bureaucratic apparatus) are critical and must be carried out so that public service can be of higher quality provide optimal satisfaction for service recipients. Data analysis techniques are carried out continuously. During the process is done coding of things found based on the context and perspective of participants. This research aimed to discover public service education in the government Gamping sub-district, Yogyakarta, so this research is phenomenological. While the approach used is ethnoscience (Sturtevant, 1964; Febu, Nuswowati, \& Sumarni, 2017).

\section{RESULTS AND DISCUSSION Humanist Public Service}

The humanist paradigm in the administration of public services, Love Lock in Hasjimzum (450-451), offers five principles that must be considered in public services so that the quality of public services can be achieved, namely: 1) tangible, providing good services as indicated by service behavior; 2) reliable, reliable and skilled, mastering the applied work fields; 3) responsiveness, a sense of responsibility towards the quality of service, meaning that every employee in providing forms of service prioritizes aspects of service that significantly affect the behavior of people who get service; 4) assurance (guarantee), public servants who know that people who receive services feel satisfied and confident that all forms of affairs will be resolved quickly and correctly; 5) Empathy, able to serve people who are served with attention to various problems that require service. Empathy is demonstrated by behavior and body language but far more important in it is that it can use good communication and contain elements of ethics and aesthetics. Therefore, one of the humanist paradigms in public service that must also be balanced is effective reciprocal communication.

Communication in public services is vital because the service process must be carried out and packaged through good communication between service providers and service users. Without good communication, the public does not know what efforts have been made by public service providers. More than that, according to Kasmawati (2011), a service is considered an excellent 
service if the design and procedures meet several principles, namely; 1) prioritizing customers; 2 ) is an effective system; 3) serving with a conscience; 4) make continuous improvements, and 5) empower customers.

Related to public services in Law No. 5 of 2014 concerning the State Civil Apparatus has been submitted that ASN employees function as; 1) Implementing public policies; 2) Public servants; and 3) Adhesives and unifying the nation (Kusumasari et al., 2015). These ASN functions must be carried out with full responsibility and can be held accountable to the public. So ASN should provide optimal public services to the community. In addition, other values that need to be upheld by ASN in providing services to the public are Accountability, Nationalism, Public Ethics, Quality Commitment, and AntiCorruption. The government has given the five aspects of value through the education and training body to ASN candidates. It is hoped that through the inculcation of these values, ASN can provide excellent and optimal services to the community. The ASN paradigm as the person served is the reverse paradigm, where ASN should provide services to the community.

We try to learn a little from child development psychology in the learning process about the first principle. A teacher or parent must know to enter the world of children, not children enter the world of teachers or parents. Likewise, good public service must try to present to the world it serves without getting out of its nature as a professional public servant. One thing that needs to be emphasized again in the humanist public service approach is providing education and training to the organizer's government bureaucracy, including character education to foster that humanist attitude. Without character education and the inculcation of the values of humanism, the public service process will seem arid (Schunk, 2012; Hirsh-Pasek et al., 2015).

\section{Service In Islam}

According to Islamic encyclopedias, service is a necessity whose operation is by sharia principles. For a service to be more directed, all parties must have guidelines and regulations as outlined in the teachings of Islam, where Islam emphasizes service by the expectations of consumers who feel the maximum satisfaction. The concept of service in Islam is as follows;

1. The Principle Please Help (ta'awun)

Providing the best service to fellow human beings is a very noble job and is a door of goodness for anyone who does it. As explained in the verses of the Qur'an:

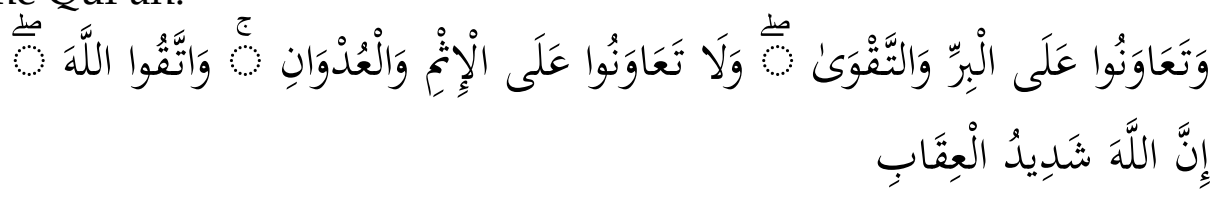

Meaning: Please help you in (doing) virtue and piety and don't help commit sins and transgressions. And fear ye Allah, verily Allah is severely tortured (al-Maidah 5: 2)

In a hadith, it is said that: Meaning: "One who shows (others) to the good, he is like doing it" (Muslim) 
The purpose of the above hadith is compared to people with knowledge to help others with their understanding; rich people help with their wealth. And Muslims should be one hand in helping people in need. So, after doing a good deed, a believer is obliged to help others with words or actions that encourage the spirit of others to do good deeds.

2. The Principle of Providing Ease (at-Taysir)

Realizing the human nature that does not like the burden that limits its independence. Allah SWT sent down Islamic Shari'ah to maintain and try so that the provisions imposed on humans can be easily implemented. They can eliminate difficulties and narrowness to stop things that complicate (masyaqah) people who are superfluous and can spend human resources implementing it.

However, this does not mean that Islamic sharia eliminates the difficulties that humans may experience in their lives. It's just expected that the provisions contained in Islamic law can reduce problems for humans. This is according to the word of Allah SWT in Surah Al-Baqarah: 185

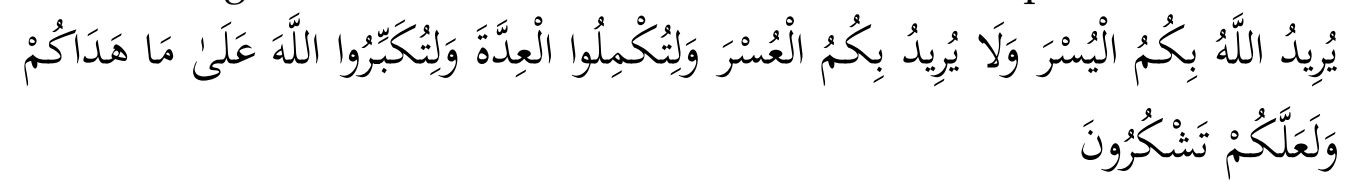

It means: "Allah wants ease for you, and does not want hardship for you. and you shall suffice the numbers and you should glorify God for His instructions given to you so that you are grateful."

As a hadith from Anas bin Mali Rahayallaahu 'Anhu, he said: Rasulullah Sallallaahu' Alaihi Wasallam said that "Make it easy and don't complicate, give them joy and don't make them run away" (Muttafaq 'Alaih)

3. The Principle of Loving Each Other (mahabbah)

A sense of mutual love that is loving one's brother is like loving yourself, where an employee provides service to customers by treating the customer well as treating himself. As explained in the Qur'an, which reads

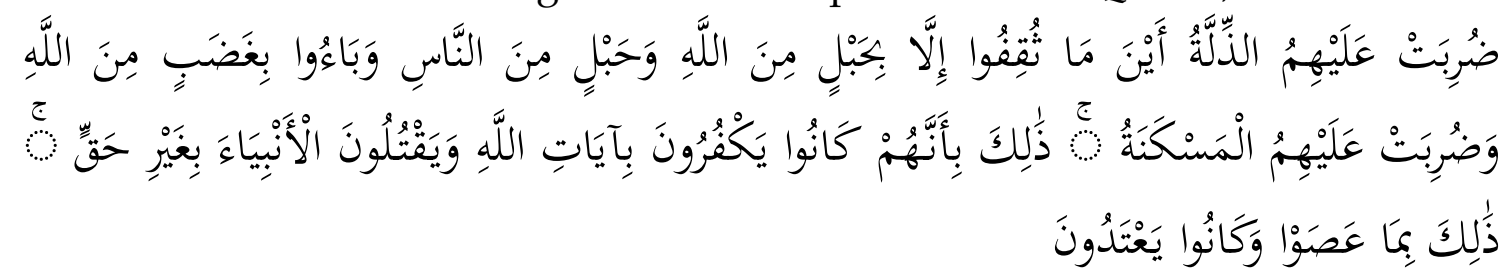

Meaning: "they are filled with humiliation wherever they are unless they hold on to the rope (religion) of Allah and the rope (agreement) with humans and they again get the wrath of God and they are overcome by humility. This is because they disbelieved in the verses of Allah and killed the Prophets without good reason. this is because they are ungodly and exceed the limits" (Ali Imran: 112).

And also, in a hadith narrated, a person's faith is not perfect until he loves his brother as he loves himself (HR. Bukhari). The essence of this hadith is "treat your brother as you treat yourself." 
4. The Principle of Meekness (al-layin)

As a hadith narrated by Muslims from Jabir bin Abdullah that the Prophet said: "Whoever does not have a gentle nature will never get good."

To be gentle is also explained in the Qur'an in the QS. Ali Imron: 159, which reads:

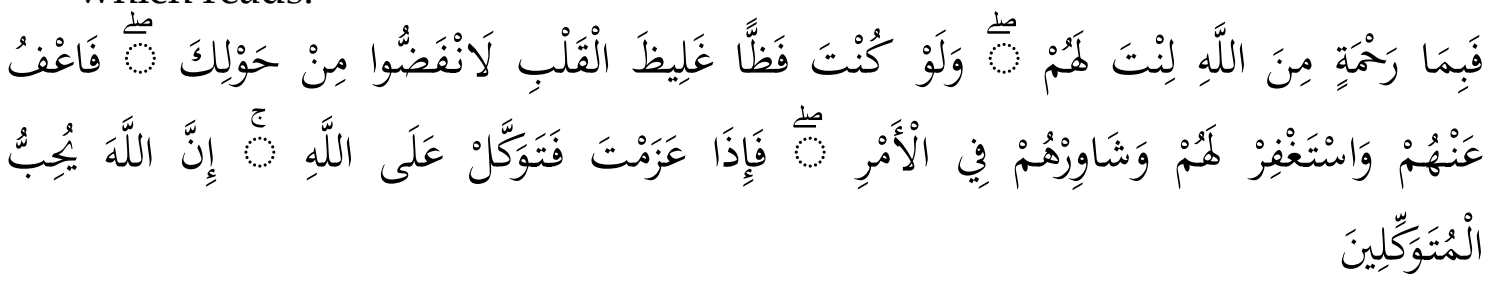

It means: "Then it is due to the grace of Allah that you are gentle to them. If you are hard and hard, they will distance themselves from your surroundings. Therefore forgive them, ask forgiveness for them, and consult with them in that matter. Then when you have made up your mind, then put your trust in Allah. Surely Allah loves those who put their trust in Him".

What is meant by being harsh here is speaking harsh words. AlHasan said, "This gentle behavior is the morality of Muhammad Sallallahu alaihi wasallam where he was sent by bringing this noble character."

5. Family principles (ukhuwah)

The brotherhood, which is clearly stated in the Qur'an, is a brotherhood of religions and brotherhood whose ties are not due to faith. This is reflected in the verses of the Qur'an Surah Al-Hujurat: 10:

It means: "Believers are indeed brothers and sisters. therefore reconcile (improve the relationship) between your two brothers and fear God, so that you may receive mercy".

The word ukhuwah (brotherhood) includes the equality of one element such as ethnicity, religion, profession, and feelings. So in the Qur'an, it is explained that ukhuwah is a brotherhood of the Muslim faith, and a brotherhood whose relationships are not due to faith. Islam emphasizes the validity of a service that has good intentions. The services that have good purposes according to Islam are; a) Services are provided according to customer expectations with maximum satisfaction; b) there is a difficulty in providing services, but consumers don't know it; c) the occurrence of a mistake in providing customer service avoids being dissatisfied with the service officer's work.

Both the Qur'an and the hadith provide specific guidelines in matters of karma for good behavior in business matters. A Muslim business person is required to behave appropriately according to the Qur'an and Sunnah. Polite is the basic foundation and core of good behavior and is also the basis of the soul to serve.

The attitude of serving is one of the Islamic principles of the Prophet, saying "saidul kaunkhalimuhum" (the manager/entrepreneur is a servant to the buyer). Therefore, a generous, friendly, and service attitude must be part of the personalities of all working employees. 


\section{Public Service in Government}

Then, related to public services in government, one of the government's most important tasks is to provide public services to the public. Public services are the provision of services by the government, private parties on behalf of the government, or private parties to the community, with or without payment to meet the needs or interests of the community. According to Robert, as quoted by Neneng (1996), public services are all forms of service activities to the public carried out by government agencies, regions, and within the state or regionalowned enterprises to meet community needs public order. The government has issued various policies as a follow-up effort to carry out public service activities.

In this regard, the interview observations that have been carried out previously are taking place at the Gamping District Office. There, we ask questions and see firsthand the services that have been implemented by civil servants who are there, especially regarding the implementation of humane services. At the Gamping District Office, the service has used Integrated Administrative Services (PATEN). The performance of PATEN in the Gamping District is seen from the physical aspect of having a counter for services but other infrastructure facilities; it needs to be improved again, such as computers. In the part of the process, it is also good because the residents give the file, wait and receive the results document in one place. In human resources, there needs to be an improvement due to the quality of officers and the number of officers who are still lacking, but residents will still be served despite the lack of officers. Then, information availability is also good because there is socialization by giving information about PATEN. Residents can participate by providing input and complaints directly to the district. Another obstacle is organizational structure because a service section is needed to deal specifically with services in the sub-district.

Based on the Minister of Home Affairs Regulation Number 24 of 2006 concerning Organizing One-Stop Integrated Services Guidelines. This Regulation of the Minister of Home Affairs regulates that implementing onestop integrated services can provide better services and provide more comprehensive access to the public. The government also issued Minister of Home Affairs Regulation No. 4 of 2010 concerning Integrated District Administrative Services (PATEN). This Policy on Integrated District Administration Services (PATEN) was created to simplify and speed up licensing/non-licensing administration services at the sub-district level, especially for sub-districts located far from district/city government offices and challenging to reach due to geographical factors and inadequate infrastructure. To induce this PATEN, the government has also issued a Decree of the Minister of Home Affairs Number 138-270 of 2010 concerning Technical Guidelines for Integrated District Administrative Services (PATEN). 


\section{CONCLUSION}

Humanism education is an integrated step to humanize human beings to shape character and realize the potential possessed by every human being to be more human. Of course, if there is the support between a conducive environment and effective mutual communication with others, education can be carried out in a balanced way by humans. So, to create a human education that provides results in the form of public services can run optimally by paying attention to the balance between the two things, namely internal and external aspects.

Then, the teachings of Islam that originate from the Koran relating to the education of humanism services through public services are necessary for its implementation by the principles of sharia. Islam strongly recommends treating humans both in themselves and in the best of others. Because providing the best service to fellow human beings is a very noble work and is a door of goodness for anyone who does it and can make it an action that stimulates the enthusiasm of others for charity.

The government is essentially a public servant who must provide the best service to meet the community's needs. For services to the public can be more functional through humanism education, which has a vital role to the community wherever and the situation at any time. Because through humanism, education is the formation and development of character to foster the humanist attitude of each person, especially the state civil apparatus. So that with the existence of character education and the inculcation of humanism values, the process of public service in government can serve the community well and maximally, which certainly can satisfy the community in terms of service.

\section{REFERENCES}

Asiah, N. (2017). Hak Asasi Manusia Perspektif Hukum Islam. DIKTUM: Jurnal Syariah dan Hukum, 15(1), 55-66.

Cahyadi, R. (2016). Inovasi kualitas pelayanan publik pemerintah daerah. Fiat Justicia Journal of Law, 10(3), 569-586.

Colbran, N. (2010). Realities and challenges in realising freedom of religion or belief in Indonesia. The International Journal of Human Rights, 14(5), 678704. https:// doi.org/10.1080/13642980903155166

Febu, R., Nuswowati, M., \& Sumarni, W. (2017). Development of Ethnoscience Approach in The Module Theme Substance Additives to Improve the Cognitive Learning Outcome and Student's entrepreneurship. Journal of Physics: Conference Series, 824, 12024. https://doi.org/10.1088/17426596/824/1/012024

Frederickson, H. G., \& Hart, D. K. (1985). The Public Service and the Patriotism of Benevolence. Public Administration Review, 45(5), 547-553. https:/ / doi.org/10.2307/3109929 
Hasjimzum, Y. (2014). Model Demokrasi dalam Peningkatan Kualitas Pelayanan Publik (Studi Otonomi Daerah dalam Peningkatan Kesejahteraan Masyarakat Pasca Reformasi). Jurnal Dinamika Hukum, 14(3), 445-457.

Hirsh-Pasek, K., Zosh, J., Golinkoff, R., Gray, J., Robb, M., \& Kaufman, J. (2015). Putting Education in "Educational" Apps: Lessons From the Science of Learning. Psychological Science in the Public Interest, 16(1), 3-34. https:/ / doi.org/10.1177/1529100615569721

Hutagalung, I. (2015). Teori-teori Komunikasi dalam Pengaruh Psikologi. Jakarta: Indeks.

Lattimore, D., Baskin, O., Heiman, S. T., \& Toth, E. L. (2010). Public Relations Profesi dan Praktik. Jakarta: Salemba Humanika.

Muali, C. (2017). Humanism Education: Affective Consideration in Character Education Conception. Proceedings of the 1 International Conference on Education and Islamic Culture "Rethinking Islamic Education Toward Cultural Transformation," 7. Probolinggo, East Java, Indonesia: Institute of Nurul Jadid.

Nurjanah, I. (2018). Paradigma Humanisme Religius Pendidikan Islam (Telaah Atas Pemikiran Abdurrahman Mas' ud). Misykat: Jurnal Ilmu-ilmu AlQuran, Hadist, Syari'ah dan Tarbiyah, 3(1), 155-170.

Prasodjo, T. (2017). Paradigma Humanis dalam Pelayanan Publik. Jurnal Ilmiah Ilmu Administrasi Publik, 7(1), 38-45.

Rezha, F. (2013). Analisis Pengaruh Kualitas Pelayanan Publik Terhadap Kepuasan Masyarakat (Studi tentang Pelayanan Perekaman Kartu Tanda Penduduk Elektronik (E-KTP) di Kota Depok). Jurnal Administrasi Publik, 1(5), 981-990.

Sari, N. (2013). The Importance of Teaching Moral Values to The Students. Journal of English and Education, 1(1), 154-162.

Schunk, D. H. (2012). Learning Theories: an Educational Perspective. Boston: Pearson.

Selinger, S. (2019). Social Learning Theory. In J. L. Lebow, A. L. Chambers, \& D. C. Breunlin (Eds.), Encyclopedia of Couple and Family Therapy (pp. 27042707). Cham: Springer International Publishing.

Sturtevant, W. C. (1964). Studies in Ethnoscience. American Anthropologist, 66(3), 99-131.

Suprapto, Y. (2016). Membaca Ulang Pendidikan Humanis (Literacy Pendidikan Humanis). Forum Ilmu Sosial, 43(1), 26-37.

Syukuri, A. (2019). Pendidikan Humanisme dalam Membangun Nilai-Nilai Kemanusiaan Religius Perspektif KH Mahfud Ridwan dan YB Mangunwijaya (Doctoral dissertation, IAIN Salatiga).

Wahyudi, R., \& DESMIWAR, D. (2018). Islam, Perilaku Aparatur Sipil Negara dan Kritik Epistimologi Ilmu Administrasi Negara. An-Nida', 41(1), 5061.

Yusriadi, Y. (2018). Bureaucratic Reform to the improvement of public services Challenges for Indonesia. Publikauma: Jurnal Administrasi Publik Universitas Medan Area, 6(1), 15-29. 